\title{
Workplace Aggression and Job Satisfaction: A Study on Employees of PT. ABC in Tangerang, Banten
}

\section{Yuanita Putri Ayuning Tyas ${ }^{1}$, Tutut Chusniyah ${ }^{1 *}$, Agung Minto Wahyu ${ }^{1}$, Lufiana Harnany Utami², and Riyan Rahmat Aminullah Basith ${ }^{1}$}

${ }^{1}$ Faculty of Psychology Education, State University of Malang, Malang, Indonesia

${ }^{2}$ Faculty of Psychology and Health, Sunan Ampel State Islamic University of Surabaya, Surabaya, Indonesia

\section{ORCID}

http://orcid.org/0000-0001-8898-4021;

http://orcid.org/0000-0001-8898-4021

https://orcid.org/0000-0001-8014-7245;

Corresponding Author: Tutut Chusniyah; email:

tutut.chusniyah.fppsi@um.ac.id

Dates

Published 28 January 2022

Publishing services provided by

Knowledge $\mathrm{E}$

(c) Yuanita Putri Ayuning Tyas et

al. This article is distributed

under the terms of the

Commons Attribution License,

which permits unrestricted use and redistribution provided that the original author and source are credited.

Selection and Peer-review under the responsibility of the ICoPsy Conference Committee.
Abstract. Job satisfaction is the positive perception of an individual about his/her job. Determinants of individual satisfaction and dissatisfaction include social factors. Workplace aggression is a social problem that occurs in the workplace. The objectives of this study were to examine: (i) the level of work aggression demonstrated by employees at PT. ABC in Tangerang Banten in the cutting subdivision; (ii) the level of job satisfaction in employees; and (iii) the relationship between aggression in the workplace and job satisfaction. Quantitative correlation methods were used. 53 participants were recruited through purposive sampling out of the population of 103 employees in the cutting subdivision. The eligibility criteria included that respondents must be registered as permanent or contract employees, not temporary employees. Data were collected using a Likert model scale instrument, consisting of: (i) a workplace aggression scale based on aggression indicators (Baron \& Branscombe); and (ii) a job satisfaction scale based on the form of expression of job dissatisfaction to employees (Robbins). The results of this study indicated that: (i) aggression at work in the cutting subdivision employees of PT. ABC in Tangerang, Banten was relatively high; (ii) job satisfaction was generally relatively low; and (iii) there was a significant relationship between aggression at work and job satisfaction.

Keywords: workplace aggression, job satisfaction, employee

\section{Introduction}

One of the job satisfaction factors is social factors related to co-workers, workgroups, norms, opportunities to interact, and the existence of informal organizations [1]. The inhibition of social factors in the work environment can result in discomfort, and one example is the presence of aggression in the workplace. Workplace aggression is a behavior related to employees to hurt the people they work with or who employ them, continues to be a common and significant organizational problem. Aggression in the

\section{G OPEN ACCESS} workplace usually arises between co-workers, seniors, and juniors, or superiors and 
subordinates. As previously discussed, social factors are things that support individual job satisfaction in their current workplace. Work aggression is an obstacle or problem in the social environment at a workplace [2].

The study results indicate that good relations between employees provide benefits for all parties so that it has a positive impact on employees. However, the phenomenon of aggression in the workplace is carried out by supervisors because employees make trivial mistakes negatively impacts [3]. Workplace aggression in verbal and physical violence cause employees to suffer and eventually leave his/her job [4]. This will result in low employee job satisfaction, leading to an ineffective organization [5].

Barling stated that violence against employees is more harmful than sexual harassment (Fakhar, 2014). However, these two things should be avoided because workers end up depressed and leave an unsettling workplace atmosphere. The presence of aggression in the workplace will impact various things, leading to an employee leaving the company. This is a form of manifestation of worker dissatisfaction. Other forms of employee dissatisfaction can be caused by constructive, active voice, passive loyalty, and neglect of orders and prohibitions [6].

Research related to workplace aggression and job satisfaction is overlooked in Indonesia. So far, research on the relationship between the two variables is still mostly done abroad [7-13]. Most of these studies were conducted on medical staff in hospitals, and there were only three studies administered on employees of private companies. Furthermore, in Indonesia, only one study discusses workplace aggression and employee satisfaction [14].

PT. ABC Tangerang Banten is a company with many employees, and the staff member tend are expected to work under constraining pressure. Previous studies indicate that supervision is the main factor that triggers aggression in the workplace. Supervisors often belittle employees and show unfair behavior to some of their staff members. On the other hand, the level of seniority is expressed by old employees to new employees, provoking conflict.

The hostility that exists due to job competition is also unavoidable for employees. This produces conflicts between employees, and even small groups are formed to mock other working staff. Another phenomenon that occurs at PT. ABC is that there seems to be a theft crime among the employees. This creates distrust, resulting in mutual suspicion, leading to aggression between employees-the trade unions at PT. Until now, $A B C$ has not been able to handle personal problems for each employee optimally.

No research has been conducted to examine the relationship between employee aggression at work and job satisfaction of PT ABC employees. This research is significant 
because in figuring out the conflict and finding the solutions, appropriate policies can be taken immediately to deal with these problems. The purpose of this study is: (i) to determine the level of aggression in the workplace on employees of PT. A B C; (ii) determine employee satisfaction at PT. A B C; (iii) examine the relationship between workplace aggression and job satisfaction on employees of PT. ABC in Tangerang, Banten. This research hypothesizes a relationship between work aggression and job satisfaction on employees of PT ABC in Tangerang, Banten.

\section{Literature Review}

\subsection{Workplace Aggression}

Workplace aggression is a deliberate attempt by an individual to hurt others they work with or have worked with or harm the organization for which they currently work or previously [15]. Aggressiveness in the workplace is affected by situational factors, including injustice, job dissatisfaction, interpersonal conflict, environmental constraints, and poor leadership, and is influenced by individual or personal factors, including nature, gender, and negative affect [16]. Factors that influence aggressiveness in the workplace are situational factors, including injustice at work, the role of stressors, cruelty perpetrated by supervision, and individual factors, including demographic and personality factors [17].

Aggressiveness is generally divided into: (i) physical aggression, aggression as violence and also attacks on others by using body parts or in response to verbal attacks; (ii) verbal aggression, the type of aggression whose purpose is to ignore, reject, threaten, and frighten; (iii) anger, internal physiological reactions and emotional expressions produced by unpleasant feelings; (iv) hostile aggression, an act of aggression that comes from feelings of anger and aims to cause pain and injury [18].

\subsection{Job Satisfaction}

Job satisfaction is a general attitude towards a person's work duty that exemplifies the difference between the number of awards workers receive and the amount they believe they should receive [6]. Attitudes relevant to job satisfaction and dissatisfaction reflect an employee's assessment of current and past work experiences rather than expectations for the future. 
Factors that affect job satisfaction include: (i) psychological factors, which are factors related to employee psychology which include interest, job security, attitude towards work, work feelings; (ii) physical factors, are factors related to the physical work environment and physical conditions of employees, including types of work, working time arrangements, work equipment, air circulation, employee health; (iii) financial factors, are factors related to employee security and welfare, which include the salary system, social security, amount of allowances, facilities provided, promotions and others; (iv) social factors, are factors related to social interaction between fellow employees, with their superiors, as well as employees with different types of work [19].

\section{Method}

The method used in this study is a quantitative correlation to determine the relationship between workplace aggression and job satisfaction of employees of PT. ABC in Tangerang, Banten. The population is 103 employees in the cutting subdivision. This research utilized purposive sampling with the criteria that respondents must be registered as permanent or contract employees, not temporary jobs. The sample used is 53 respondents.

Data collection was carried out using a Likert model scale instrument, consisting of: (i) workplace aggression scale based on aggression indicators that occur at work falling into three main categories. They are hostility and non-aggression, direct (sabotage), and direct (open) aggression [20]; (ii) job satisfaction scale is based on the form of expression of job dissatisfaction to employees. The expression is divided into four forms: employee leave, voice, loyalty, and abandonment [6]. Data analysis was carried through with Pearson's product-moment correlation to answer the pre-determined hypothesis.

\section{Results}

\subsection{Descriptive Analysis}

The results of the descriptive analysis on the research subjects were 53 subjects, the lowest score was 42 , the highest score was 86 , the mean was 64.58 , and the standard deviation was 10,716 . Of the 53 employees of the company who became the research subject, 25 subjects (47.17\%) experienced a low level of work aggression, and 28 subjects (52.83\%) experienced a high level of work aggression. Hence, it can be 
TABLE 1: Normality test results

\begin{tabular}{l|l|l|l|} 
Variable & KS-Z & $\begin{array}{l}\text { Significance } \\
\text { tailed) }\end{array}$ & (2- Inference \\
\hline Aggression at work & 0,855 & 0,457 & Normal \\
\hline Job satisfaction & 0,850 & 0,465 & Normal \\
\hline
\end{tabular}

TABLE 2: Linearity test results.

\begin{tabular}{|c|c|c|c|}
\hline Variable & F & Significance & Inference \\
\hline $\begin{array}{l}\text { Aggression at work - } \\
\text { Job Satisfaction }\end{array}$ & 54,514 & 0,000 & Linear \\
\hline
\end{tabular}

concluded that the level of aggression in the company PT. ABC in Tangerang Banten cutting sub-division is relatively high.

The results of the descriptive analysis on the research subjects were 53 subjects, the lowest score was 39 , the highest score was 72 , the mean was 54.85 , and the standard deviation was 8.097. Research subjects as many as 25 subjects (47.17\%) have a higher employee satisfaction than 28 subjects (52.83\%) have a lower level of job satisfaction. Therefore, the data analysis discloses that the level of job satisfaction at the company is relatively low.

\subsection{Normality Test}

Based on the table above, it can be seen that the workplace aggression variable has a significant value with a probability of $p=0.457$ (or $p>0.05$ ). Meanwhile, the normality test results on the job satisfaction variable have a significant value with a probability of $0.465(p=0.465)$ or $p>0.05$. Thus, it can be concluded that the data of the two research variables have a normal distribution of data.

\subsection{Linearity Test}

Based on the linearity test in the table above, the relationship between workplace aggression and job satisfaction has a significant probability value of sig $=0.000$ or sig $<0.05$. So that the relationship between the variables of aggression at work and job satisfaction shows the direction or straight, based on the normality test and linearity test, it was shown that the research data of the two variables were regular and linear so that the correlation analysis could be continued. 
TABLE 3: Relationship between aggression at work and job satisfaction

\begin{tabular}{|c|c|c|}
\hline Variable & Pearson Correlation & Significance (two-tailed) \\
\hline $\begin{array}{l}\text { Aggression at work - Job } \\
\text { Satisfaction }\end{array}$ & 0,625 & 0,000 \\
\hline
\end{tabular}

\subsection{Hypothesis Testing}

Based on the table above, it can be seen that the results of hypothesis testing between workplace aggression and employee job satisfaction have a correlation coefficient of 0.625 with a significance of $0.000(p<0.000)$. It happens that the scale used to measure job satisfaction is the employee job dissatisfaction scale. Job dissatisfaction caused the result to be low in job satisfaction. It can be concluded that aggression in the workplace represents a negative relationship with job satisfaction on employees of PT. ABC in Tangerang Banten cutting sub division. Simply put, if aggression at work is high, then job satisfaction is low, and vice versa; if aggression at work is low, then job satisfaction is high.

\section{Discussion}

The results of this study indicate that aggression at work with job satisfaction is negatively correlated. The results of this study are in line with several other studies [7-11,14]. On the other hand, only one study has different results from this study [12].

Job satisfaction is measured using the level of disclosure of job dissatisfaction, which is the opposite of high job satisfaction. Dissatisfaction that is higher than satisfaction in employees will lead to abandonment. The neglect in question is the disclosure of job dissatisfaction passively, lowering performance, production, absenteeism, truancy, and indiscipline [6].

While work aggression that occurred at PT. ABC is more likely to refer to verbal and symbolic aggression (such as facial expressions of hostility, disgust, looking away). Aggression in the workplace experienced by employees is also between individuals or co-workers. Violence between subordinates and superiors rarely appears because employees have a labor union called the SPN; this union will protect the rights of employees. The union will get involved when employees experience aggression which then violates employee rights. However, it is worth noting that the union only protects employees from aggression between the employees and the company. Any other conflicts should be settled personally. 
Furthermore, in this study, one of the factors that affect employee job satisfaction is social factors. As mentioned above, social factors have a relationship between job satisfaction with colleagues, workgroups and norms, opportunities for interaction, and informal organization. Social factors also form job dissatisfaction if not achieved. If there is aggression at work, it affects the relationship between social factors hence impacting employee satisfaction. Aggression in the workplace usually occurs among co-workers, superiors, clients within their company. Based on the analysis, it can be deduced that workplace aggression is significantly relevant to job dissatisfaction [1].

The form of aggression examined in this study is depicting aggression in a workplace by fellow employees. Unions that act as employee protectors only solve problems between employees and the company, not among employees. For example, the slightest theft against the company can result in employees being threatened with expulsion and dealing with the authorities. However, the situation is different when the theft is committed on a co-worker. The union will help employees to stay in the company because they believe that it is no harm. Unfortunately, this allows for the repetitive crime of stealing

However, this act of aggression did cause any other employees to leave. They prefer to keep working, and some even reach 12 years of working at the same place. They are more likely to express their discontent as a way of neglect, as described earlier. This can be determined by several factors other than social factors. According to Lawyer, job satisfaction can be identified by the individual's perception of the amount of income he/she should receive based on his work performance assessment results with the perception of the income he/she receives. It is presumed that employees are satisfied with their compensation, although they are not satisfied with the working environment. Hence, they express a form of dissatisfaction with a passive and covert attitude towards the company [21].

\section{Conclusion}

Aggression at work affects employees of PT. ABC Tangerang Banten, and it appears to happen quite often. Based on the analysis, job satisfaction scores are low, and the measurements prove it by disclosing employee job dissatisfaction. Therefore, it can be stated that there is a significant relationship between workplace aggression and job satisfaction.

Based on the results of this research, the researchers have provided practical suggestions, such as: (i) the company should follow up on acts of aggression in the workplace, 
especially for supervisors of any sub-division; (ii) company employees are expected to minimize acts of aggression that occur in the workplace, especially in verbal and symbolic forms of workplace aggression; (iii) pay close attention to the disclosure of job dissatisfaction to employees so as not to have an impact on that is detrimental to the company; (iv) if the company is unable to identify the job satisfaction of each employee, it is suggested each head of the sub-division inspect the satisfaction of each employee.

Suggestions for further research are that: (i) extensive research should be done in delineating the relationship between superiors and subordinates in any company regarding workplace aggression and job satisfaction, and (ii) collect additional data to possess varied results by adding other variables such as gender or organizational culture.

\section{Acknowledge, Funding \& Ethic Policies}

Thanks to PT. ABC which has allowed its employees to be respondents in this study. The authors received financial support from Faculty of Educational Psychology, State University of Malang for the research, authorship, and publication of this article.

\section{References}

[1] Mullins LJ. Management and organisational behaviour. Eleventh Edition. Harlow, England New York: Pearson; 2016. 649 p. (Always learning).

[2] Linsley P. Violence and aggression in the workplace: a practical guide for all healthcare staff. London: CRC Press; 2018.

[3] Aslam A, Riani AL, Widodo GP. PENGARUH PERILAKU KERJA, LINGKUNGAN KERJA, DAN INTERAKSI SOSIAL TERHADAP KEPUASAN KERJA. JURNAL MANAJEMEN DAN PELAYANAN FARMASI ( Journal of Management and Pharmacy Practice). 2013 Sep 10;3(3):167-74. doi: 10.22146/jmpf.189

[4] Novarina ES. Analisis kasus sumber daya mananusia pada NIKE, Inc di Indonesia (Upah, jam kerja, usia pegawai, uang lembur dan pesangon) [Internet]. Bogor; 2012 [cited 2021 Nov 29]. Available from: https://www.academia.edu/35611678/ TUGAS_INDIVIDU_MATA_KULIAH_ORGANISASI_DAN_SUMBER_DAYA_MANUSIA

[5] Robbins SP, Judge TA. Perilaku Organisasi / Stephen P. Robbins I Perpustakaan STIE MADANI [Internet]. Jakarta: Salemba Empat; [cited 2021 Nov 29]. Available from: http://madani-perpus.ip-dynamic.com/inlislite3/opac/detail-opac?id=1858 
[6] Robbins SP. Prinsip-prinsip perilaku organisasi. Edisi 5 / Stephen P. Robbins; alih bahasa Halida; Dewi Sartika. 5th ed. Mahanani N, editor. Jakarta: Erlangga; 2015.

[7] Caillier JG. The Impact of Workplace Aggression on Employee Satisfaction With Job Stress, Meaningfulness of Work, and Turnover Intentions. Public Personnel Management. 2021 Jun;50(2):159-82. https://doi.org/10.1177/0091026019899976

[8] Jaradat Y, Nielsen MB, Kristensen P, Nijem K, Bjertness E, Stigum H, et al. Workplace aggression, psychological distress, and job satisfaction among Palestinian nurses: A cross-sectional study. Applied Nursing Research. 2016 Nov;32(November 2016):1908. doi: 10.1016/J.APNR.2016.07.014.

[9] Jaradat Y, Nielsen MB, Kristensen P, Nijem K, Bjertness E, Bast-Pettersen R. Mental distress and job satisfaction in Palestinian nurses exposed to workplace aggression: a cross-sectional study. The Lancet. 2018 Feb;391(Supplement 1):S37. doi: 10.1016/S0140-6736(18)30362-3.

[10] Hills D, Joyce CM. Workplace aggression in clinical medical practice: associations with job satisfaction, life satisfaction and self-rated health. Medical Journal of Australia. 2014 Nov;201(9):535-40. doi: 10.5694/MJA13.00152.

[11] Pseekos AC, Bullock-Yowell E, Dahlen ER. examining holland's personenvironment fit, workplace aggression, interpersonal conflict, and job satisfaction. Journal of Employment Counseling. 2011 Jun;48(2):63-71. doi: 10.1002/J.21611920.2011.TB00115.X.

[12] Grizzle TL. Relationship between workplace aggression and employee job satisfaction [Internet]. [Minneapolis, United States]: Walden University; 2016. Available from: https://scholarworks.waldenu.edu/dissertations/3032/

[13] Demir D, Rodwell J. Psychosocial Antecedents and Consequences of Workplace Aggression for Hospital Nurses: Antecedents and Consequences of Aggression. Journal of Nursing Scholarship. 2012 Dec;44(4):376-84. doi: 10.1111/J.15475069.2012.01472.X.

[14] Pangestu KA. Hubungan antara workplace aggression dan kepuasan kerja karyawan di Departemen Polyester PT. Bineatama Kayone Lestari Tasikmalaya. [Bandung]: Parahyangan Catholic University; 2017.

[15] Greenberg J, Baron RA. Behavior in Organizations. New Jersey: Pearson Prentice Hall; 2008. 808 p.

[16] Hershcovis MS, Turner N, Barling J, Arnold KA, Dupré KE, Inness M, et al. Predicting workplace aggression: A meta-analysis. Journal of Applied Psychology. 2007;92(1):228-38. doi: 10.1037/0021-9010.92.1.228 
[17] Langan-Fox J, Cooper CL, Klimoski RJ. Research Companion to the Dysfunctional Workplace: Management Challenges and Symptoms. Massachusets: Edward Elgar Publishing; 2007. 495 p.

[18] Aronson E, Wilson TD, Sommers SR, Akert RM. Social Psychology. London: Pearson; 2016. $602 \mathrm{p}$.

[19] Anorogo P. Psikologi dalam perusahaan. Jakarta: Rineka Cipta; 1993.

[20] Baron RA, Branscombe NR. Social Psychology. New Jersey: Pearson; 2012. 509 p.

[21] Wijono S. Psikologi industri dan organisasi?: Dalam suatu bidang gerak psiokologi sumber daya manusia. Kencana; 2010. 